„Kwartalnik Filmowy” nr 109 (2020)

ISSN: 0452-9502 (Print) ISSN: 2719-2725 (Online)

https://doi.org/10.36744/kf.272

(C) Creative Commons BY-NC-ND 4.0

Krzysztof Loska

Uniwersytet Jagielloński

https://orcid.org/o0oo-0003-4078-798X

\title{
Historie polskich emigrantów w kinie europejskim
}

\author{
Slowa kluczowe: \\ kino europejskie; \\ migracja; \\ polscy migranci
}

\begin{abstract}
Abstrakt
Recenzja książki Krisa Van Heuckeloma Polish Migrants in European Film 1918-2017 (2019). Belgijski filmoznawca zwraca uwagę na podstawowe problemy dotyczące motywu migracji: konieczność powiązania aspektów lokalnych i globalnych w badaniach nad historią kina, możliwość usytuowania produkcji filmowej w transnarodowej perspektywie oraz zmienność ekranowego wizerunku polskich migrantów w czasie. Kris Van Heuckelom próbuje odpowiedzieć na pytanie, w jaki sposób kino podtrzymywało stereotypowe wyobrażenia oraz w jakim stopniu odzwierciedlało pewien sposób myślenia, zgodnie z którym Wschód przeciwstawiony jest Zachodowi, a tradycja - nowoczesności. Chronologiczny układ książki pozwolił autorowi nie tylko na uchwycenie istotnych zmian politycznych i społecznych zachodzących na naszym kontynencie, ale również na ukazanie ich wpływu na sposoby przedstawiania migrantów. Pod względem poznawczym szczególnie wartościowe są te fragmenty książki, w których Van Heuckelom konstruuje swój wywód, sięgając po filmy rzadko przywoływane przez innych autorów oraz zwracając uwagę na ich odmienność od dominującego wzorca.
\end{abstract}




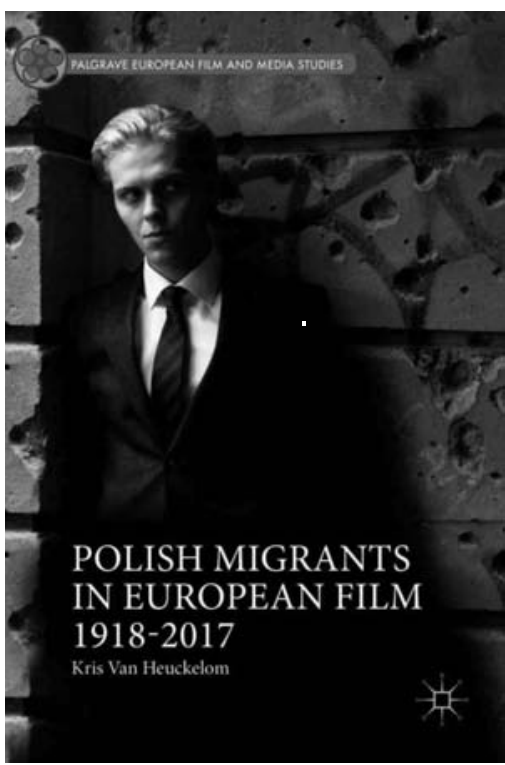

Współczesne dyskusje na temat ruchów migracyjnych, wspólnot diasporycznych oraz ich medialnych reprezentacji zazwyczaj są powiązane z analizą globalnej sytuacji społeczno-politycznej, która przyczyniła się do rosnącej fali uchodźców szukających schronienia w krajach europejskich. Przekonują o tym również liczne publikacje filmoznawcze, których autorzy omawiają problematykę migracyjną w kinie francuskim, włoskim, hiszpańskim czy brytyjskim, zwracając przy tym uwagę na postkolonialne dziedzictwo warunkujące przepływy ludzi, towarów i usług 1 .

Nieco na obrzeżach tego głównego nurtu refleksji sytuuje się książka Krisa Van Heuckeloma, profesora Katolickiego Uniwersytetu Lowańskiego, o wymownym tytule Polish Migrants in European Film 1918-2017, która wyróżnia się podejściem diachronicznym, rzadko spotykanym w podobnych publikacjach². Belgijski filmoznawca, bardzo dobrze władający językiem polskim i korzystający z polskojęzycznych źródeł, podjął się zadania, którego nie wykonali rodzimi historycy kina, mianowicie dokonał wieloaspektowej analizy około 150 filmów europejskich, w których pojawiają się polscy imigranci w rolach pierwszo- i drugoplanowych, a nawet $\mathrm{w}$ epizodach.

Punktem wyjścia tej niezwykłej opowieści o losach polskiej emigracji jest rok odzyskania niepodległości, a zarazem data niemieckiej premiery melodramatu Mania: Historia pracownicy fabryki papierosów (Mania: Die Geschichte einer Zigarettenarbeiterin, 1918, Eugen Illés) z Polą Negri w roli tytułowej ${ }^{3}$. Natomiast wizualna historia kończy się na obrazie Urszuli Antoniak Pomiędzy stowami (Beyond Words, 2017), z którego pochodzi kadr wykorzystany na okładce. Wielka szkoda, że autor złożył książkę do druku jeszcze przed premierą Zimnej wojny Pawła Pawlikowskiego, ponieważ znalazłby w tym dziele idealne dopełnienie motywu przewijającego się w kolejnych rozdziałach, mianowicie historii rodzinnej rozwijającej się w cieniu wydarzeń politycznych będących konsekwencją podziału Europy na część wschodnią i zachodnią.

Krisa Van Heuckeloma interesują powiązania aspektów lokalnych i globalnych, zmienność wizerunku emigrantów w czasie oraz możliwości usytuowania produkcji filmowej w perspektywie transnarodowej. Pomimo bardzo szerokiego spektrum zainteresowania autor wyłącza z rozważań trzy obszary tematyczne, co przekonująco uzasadnia we wstępie. Po pierwsze, pomija problematykę związaną z Holocaustem oraz losami polskich Żydów (zarówno w okresie międzywojennym, jak i powojennym); po drugie, nie uwzględnia historii przymusowych deportacji i opowieści o jeńcach przetrzymywanych w obozach (jak np. The Colditz Story Guya Hamiltona z 1955 r.); po trzecie, nie bierze pod uwagę filmów wyprodukowanych w Polsce bez wsparcia zagranicznych wytwórni.

Zawarty w książce materiał analityczny okazał się nie tylko w pełni wystarczający, ale przede wszystkim odkrywczy, jako że autor włączył wiele produkcji telewizyjnych, utworów nierzadko zapomnianych, które nawet $\mathrm{w}$ chwili premiery miały ograniczoną dystrybucję. Dlatego fascynującym, a być może niezbędnym dodatkiem do książki jest strona internetowa (http://polishmigrantsineuropeanfilm.eu), na której czytelnicy mogą znaleźć fotosy i fragmenty filmów omawianych w kolejnych rozdziałach. 
Zgodnie z przyjętymi założeniami w książce obowiązuje układ chronologiczny, z tym że analizy filmów poprzedza rozdział o charakterze teoretyczno-metodologicznym, w którym autor wyjaśnia między innymi dwa kluczowe terminy wyznaczające główną oś tematyczną - europejskość i modernizację. Pierwszy z nich wskazuje na złożoną dynamikę właczenia i wykluczenia: oddzielenia tych, którzy moga być wewnatrz, od tych, którzy musza pozostać na zewnątrz. Z kolei kwestia modernizacji dotyczy w mniejszym stopniu tożsamości i przynależności, w większym zaś działania i organizacji (s. 31-32), czyli warunków społeczno-ekonomicznych, systemów wartości oraz stosunków międzyludzkich. Podstawowe znaczenie dla zrozumienia książki mają dwie dodatkowe kategorie powracające w tekście: nostalgiczność - rozumiana zgodnie z ustaleniami poczynionymi przez Svetlanę Boym w jej znakomitej pracy The Future of Nostalgia - oraz pojęcie „bliskich Innych”, którym autor posługuje się opisując wizerunki polskich emigrantów w filmach zachodnioeuropejskich. W warstwie metodologicznej Van Heuckelom odnosi się również do koncepcji Hamida Naficy'ego, który w książce na temat „kina z akcentem” (accented cinema) posłużył się Bachtinowską kategorią chronotopu dla opisania doświadczenia twórców diasporycznych ${ }^{4}$.

W rozdziale drugim ważną rolę odgrywa nakreślone tło historyczne polskich ruchów migracyjnych, których przyczynami były: utrata niepodległości, zabory, nieudane zrywy powstańcze i zsyłki na Syberię. Wszystko to wyrasta z romantyczno-narodowego paradygmatu, w którym opuszczenie ojczyzny oraz zmiana miejsca zamieszkania łączy się z poczuciem straty i wykorzenienia (stąd przywiązanie bohaterów do przeszłości, idealizacja rodzinnych stron, a wreszcie nostalgia). Van Heuckelom zauważył, że zarówno w literaturze pięknej, jak i w filmach powraca motyw ambiwalentnego stosunku mieszkańców krajów przyjmujących do przybyszów ze Wschodu, począwszy od nieskrywanej niechęci przez obojętność do współczucia. Obcy naruszają ład społeczny lub są zbyt przywiązani do tradycji, wskutek czego zagrażają idei nowoczesności.

W pięciu rozdziałach autor omawia zmieniające się wizerunki polskich migrantów. Zaczyna od kina międzywojennego oraz trzech gwiazd, które występowały w filmach podejmujących omawianą problematykę. O ile Pola Negri i Jan Kiepura są znani wszystkim miłośnikom X muzy ze względu na ich międzynarodową sławę oraz udział w zagranicznych produkcjach filmowych, o tyle nazwisko rumuńskiej aktorki Elviry Popescu (1894-1993) zapewne kojarzą wyłącznie wielbiciele komedii francuskiej lat 30. i może właśnie dlatego to jej Van Heuckelom poświęcił najwięcej miejsca (s. 50-57). Odtwarzane przez nią postacie - nierzadko mieszanego, polsko-rosyjskiego pochodzenia, jak w Moim kuzynie z Warszawy (Ma cousine de Varsovie, 1931, Carmine Gallone) wyróżniały się swoistą ekscentrycznością oraz nieprzeciętną urodą. Zacieranie wyrazistego pochodzenia narodowego przez zaakcentowanie nieokreślonej słowiańskości stało się typową strategią przedstawiania wykorzystywaną również w innych filmach z jej udziałem: W imieniu prawa (Au nom de la loi, 1932, Maurice Tourneur) i Dziewięciu kawalerów (Ils étaient neuf célibataires, 1939, Sacha Guitry).

Jako wielbiciel opery odrobinę żałuję, że nie znalazło się więcej miejsca na omówienie kariery filmowej Jana Kiepury, najpopularniejszego polskiego tenora tamtych czasów. Zapewne wynika to $\mathrm{z}$ faktu, że prawie zawsze grywał on włoskich (a nie polskich) śpiewaków, o czym świadczą imiona i nazwiska bohaterów: Giovanni Cavallone w Neapol, śpiewające miasto (Die Singende Stadt, 1930, Carmine Gallone), Enrico Ferraro w Pieśń nocy (Das Lied einer Nacht, 1932, Anatole Litvak), Mario Delmonti w Dla ciebie śpiewam (Mein Herz ruft nach dir, 1934, Carmine Gallone). Do nielicznych wyjątków należy postać o swojsko brzmiącym nazwisku Kowalski z filmu W blasku stońca (Opernring, 1936, Carmine Gallone).

Czwarty rozdział - pod wymownym tytułem Od wysiedlenia przez ucieczkę do imigracji - został poświęcony filmom nakręconym od wybuchu drugiej wojny światowej po 
zryw solidarnościowy, czyli w czasach "zimnej wojny”, nowego podziału geopolitycznego świata, zamkniętych granic, ograniczonej mobilności, co oznaczało, że kariera międzynarodowa stała się możliwa tylko dla tych, którzy zdecydowali się na opuszczenie ojczyzny, by wymienić tu choćby Romana Polańskiego i Jerzego Skolimowskiego. Jak słusznie zauważył Van Heuckelom, w okresie powojennym zmieniły się sposoby przedstawiania polskiej emigracji, ale z drugiej strony wciąż przeważały wizerunki stereotypowe, jak chociażby w "muzycznej fantazji”, którą zaproponował Jean Renoir w filmie Helena i mężczyźni (Eléna et les hommes, 1956), gdzie Ingrid Bergman zagrała polską arystokratkę.

Autor książki zwrócił uwagę na wyraźny wzrost zainteresowania losami Polaków w kinie brytyjskim, co tłumaczył ówczesną sytuacją polityczną. Wiele osób walczących po stronie aliantów zrezygnowało z powrotu do ojczyzny rządzonej przez komunistów i przyjęło obywatelstwo brytyjskie. Jeden z pierwszych powojennych filmów z polskim wątkiem nakręcili Muriel Box i Bernard Knowles. Akcja Zagubionych ludzi (The Lost People, 1949) rozgrywa się w teatrze, którego właściciele udzielają schronienia uchodźcom serbskim, chorwackim, rosyjskim i polskim. Zupełnie inny charakter miały dwa thrillery szpiegowskie, o których pisze Van Heuckelom. W They Can't Hang Me (1955, Val Guest) pojawił się wątek polskiego oficera RAF-u podejrzewanego o szpiegostwo na rzecz Sowietów, oraz w adaptacji powieści Johna Le Carré Ze śmiertelnego zimna (The Spy Who Came In from the Cold, 1965, Martin Ritt) mamy opowieść o tajnej misji brytyjskiego wywiadu, której celem jest wywiezienie polskiego agenta zza żelaznej kurtyny. Van Heuckelom zwrócił uwagę na fakt, że w wielu filmach powraca pewien stały sposób charakteryzowania Polaków jako szaleńczo odważnych i gotowych do poświęcenia życia, ale równocześnie outsiderów. W tym obszernym rozdziale oprócz filmów brytyjskich pojawiają się również analizy produkcji włoskich - niezwykle interesujący jest fragment poświęcony Oszustom (I Magliari, 1959, Francesco Rosi) - francuskich (Lokator Romana Polańskiego), belgijskich oraz szwedzkich (Cesarz Jösty Hagelbäcka z 1979 r.).

Wydarzenia polityczne z lat 1980-1982 (strajki sierpniowe, stan wojenny) stanowią tło historyczne filmów, którymi Van Heuckelom zajmuje się w rozdziale piątym. W tym okresie powstało kilka dzieł nakręconych przez uznanych reżyserów, które w sposób mniej lub bardziej bezpośredni przywoływały tamte wydarzenia, jak Fucha (Moonlightning, 1982, Jerzy Skolimowski), Pasja (Passion, 1982, Jean-Luc Godard) czy Najlepsza zemsta jest sukces (Success is the Best Revenge, 1984, Jerzy Skolimowski). Wydaje mi się jednak, że ciekawsze i bardziej odkrywcze są te fragmenty książki, które zostały poświęcone mniej znanym produkcjom, jak chociażby Przeprawie (Traversées, 1983) Mahmouda Ben Mahmouda, który skupił się na podobieństwie losów dwóch uchodźców - Polaka i Tunezyjczyka - próbujących (bezskutecznie) przedostać się do Wielkiej Brytanii. Motywem fabularnym, który powraca w kilku innych analizowanych przez Van Heuckeloma filmach jest pewien szczególny sposób legalizowania pobytu za pomocą zawierania „papierowych małżeństw”, o czym opowiadają Charles Nemes w Chłodnych zaręczynach (La fiancée qui venait du froid, 1983) i Peter Kassovitz w Papierowym małżenstwie (Mariage blanc, 1986) z Danielem Olbrychskim w roli głównej.

Upadek komunizmu i otwarcie granic zapoczątkowały falę emigracji zarobkowej i to temu zjawisku poświęcono najwięcej uwagi w filmach fabularnych z lat 90., które są przedmiotem analizy w rozdziale szóstym. Van Heuckelom wybiera nie tylko utwory dobrze znane w Polsce, jak Trzy kolory: Biały (1994, Krzysztof Kieślowski) i Mała apokalipsa (La Petite apocalypse, 1992, Costa-Gavras), ale również takie, które miały ograniczoną dystrybucję, jak na przykład Na czarno (Le clandestin, 1994, Jean-Louis Bertuccelli) ze Zbigniewem Zamachowskim w roli nielegalnie pracującego w Paryżu robotnika budowlanego oraz Kochankowie (Les amoreux, 1994, Catherine Corsini) z Olafem Lubaszenko. Autor książki za- 
uważył, że wizerunek polskiego emigranta w filmach zachodnich reżyserów został zdominowany przez figurę robotnika, czasami idealizowanego (pracowitość, solidność itp.), czasami zaś charakteryzowanego negatywnie ze względu na nieprzystosowanie lub nieumiejętność utrzymania stałej pracy. We wszystkich omawianych przykładach Van Heuckelom zwraca uwagę na przenikanie się sfery publicznej i prywatnej, na kwestię stosunku do procesów modernizacyjnych, co się wiąże z ukazaniem losów tych, którzy padli ofiarą przemian (stąd tytuł rozdziału Kapitalizm bez ludzkiej twarzy).

Kolejną cezurą czasową dla belgijskiego filmoznawcy jest rok 2004, czyli przystąpienie Polski do Unii Europejskiej. W połowie dekady następuje dalszy wzrost ruchów migracyjnych, jednak tym razem na ekranach zamiast robotników pojawiają się również ludzie sukcesu, dobrze wykształceni i znający języki obce, jak Maciek (Marcin Dorociński), profesor SGH, w którym zakochuje się duńska fotografka modowa w filmie Kobieta, która pragnęta mężczyzny (The Woman Who Dreamt of a Man, 2010, Per Fly). Niektórzy Polacy z powodzeniem ukrywają swoje pochodzenie, jak główny bohater Pomiędzy słowami - grany przez Jakuba Gierszała młody prawnik mieszkający w Berlinie. W przedostatnim rozdziale Van Heuckelom zwrócił uwagę na nowe zjawisko, mianowicie rozwój międzynarodowych koprodukcji oraz znaczącą obecność młodego pokolenia polskich reżyserów w kinie europejskim: Małgorzaty Szumowskiej, Jacka Borcucha, Urszuli Antoniak, Pawła Pawlikowskiego, Rafaela Lewandowskiego i Julii Kowalskiej.

Niewątpliwie Polish Migrants in European Film 1918-2017 jest książką, która może uświadomić czytelnikom, jak zmienił się ekranowy wizerunek Polaków w krajach zachodnioeuropejskich $\mathrm{w}$ ciągu stu lat, $\mathrm{w}$ jakim stopniu kino podtrzymywało stereotypowe wyobrażenia oraz na ile odzwierciedlało pewien sposób myślenia, zgodnie z którym Wschód przeciwstawiony jest Zachodowi, a tradycja - nowoczesności. W wielu filmach omawianych przez Krisa Van Heuckeloma polscy migranci są portretowani jako „bliscy Inni” - podobni ze względu na wspólne dziedzictwo kulturowe czy kolor skóry, ale jednocześnie różni, ponieważ zamieszkują obszar peryferyjny kojarzony z zacofaniem. Obowiązujący w książce układ chronologiczny pozwolił autorowi nie tylko na uchwycenie istotnych zmian politycznych i społecznych zachodzących na naszym kontynencie, ale również ukazanie ich wpływu na sposoby przedstawiania migrantów. Pod względem poznawczym szczególnie wartościowe są te fragmenty książki, w których Van Heuckelom konstruuje swój wywód, sięgając po filmy rzadko przywoływane przez innych autorów oraz zwraca uwagę na ich odmienność od dominującego wzorca. Pozostaje jedynie mieć nadzieję, że książka szybko znajdzie polskiego wydawcę nie tylko ze względu na jej pionierski charakter, ale przede wszystkim wnikliwe spojrzenie na filmowy obraz Polaków żyjących na emigracji.

Kris Van Heuckelom, Polish Migrants in European Film 1918-2017, Plagrave Macmillan, Cham 2019, 283 s.

1 Warto wskazać kilka najważniejszych książek z ostatnich lat: I. Ballesteros, Immigration Cinema in the New Europe, Intellect, Bristol 2015; D. Bergham, Far-Flung Families in Film: The Diasporic Family in Contemporary European Cinema, Edinburgh University Press, Edinburgh 2013; T. G. Deveny, Migration in Contemporary Hispanic Cinema, The Scarecrow Press, Maryland 2012;
Á. O'Healy, Migrant Anxieties: Italian Cinema in a Transnational Frame, Indiana University Press, Bloomington 2018; Y. Loshitzky, Screening Strangers: Migration and Diaspora in Contemporary European Cinema, Indiana University Press, Bloomington 2010.

${ }^{2}$ Do wyjątków należy artykuł I. Santaolalli, Body Matters: Immigrants in Recent Spanish, Italian and Greek Cinemas, w: European Cine- 
ma in Motion. Migrant and Diasporic Film in Contemporary Europe, red. D. Berghahn, C. Sternberg, Palgrave Macmillan, New York 2010, s. 152-174.

${ }^{3}$ Film ten przed wiele lat uchodził za zaginiony, jednak udało się go odnaleźć i odkupić kopię od czeskiego kolekcjonera. W 2011 r. odbyła się uroczysta premiera materiałów odrestaurowanych cyfrowo, a Marek Maldis nakręcił krótkometrażowy dokument Nitro Mania opowiadający o historii tego filmu.

${ }^{4}$ H. Naficy, An Accented Cinema: Exilic and Diasporic Filmmaking, Princeton University Press, Princeton 2001.

\section{Krzysztof Loska}

Profesor zwyczajny w Uniwersytecie Jagiellońskim, dyrektor Instytutu Sztuk Audiowizualnych tejże uczelni, wiceprezes Polskiego Towarzystwa Badań nad Filmem i Mediami; zajmuje się historią filmu, zwłaszcza kinem azjatyckim. Autor stu pięćdziesięciu artykułów naukowych (publikowanych w „Kwartalniku Filmowym”, „Studiach Filmoznawczych”, „Przeglądzie Kulturoznawczym”, „Ekranach”, „Kulturze Współczesnej”, „Ethosie” i in.) oraz dwunastu książek, m.in.: Dziedzictwo McLuhana - między nowoczesnościa a ponowoczesnościa (2001), Hitchcock: autor wéśód gatunków (2002), David Cronenberg: rozpad ciała, rozpad gatunku (2003, wspólnie z A. Pitrusem), Tożsamość i media. O filmach Atoma Egoyana (2006), Poetyka filmu japonskiego (2009), Kenji Mizoguchi i wyobraźnia melodramatyczna (2012), Nowy film japonski (2013), Mistrzowie kina japońskiego (2015), Postkolonialna Europa. Etnoobrazy wspótczesnego kina (2016).

\section{Bibliografia}

Ballesteros, I. (2015). Immigration Cinema in the New Europe. Bristol: Intellect.

Bergham, D. (2013). Far-Flung Families in Film: The Diasporic Family in Contemporary European Cinema. Edinburgh: Edinburgh University Press.

Deveny, T. G. (2012). Migration in Contemporary Hispanic Cinema. Lanham: The Scarecrow Press.

Loshitzky, Y. (2010). Screening Strangers: Migration and Diaspora in Contemporary European Cinema. Bloomington: Indiana University Press.

O'Healy, Á. (2018). Migrant Anxieties: Italian Cinema in a Transnational Frame. Bloomington: Indiana University Press.

Santaolalla, I. (2010). Body Matters: Immigrants in Recent Spanish, Italian and Greek Cinemas. W: D. Berghahn, C. Sternberg, C. (red.), European Cinema in Motion. Migrant and Diasporic Film in Contemporary Europe (ss. 152-174). New York: Palgrave Macmillan.

Van Heuckelom, K. (2019). Polish Migrants in European Film 1918-2017. Cham: Palgrave Macmillan.

\section{Keywords:}

European cinema; migration;

Polish migrants

\section{Abstract \\ Krzysztof Loska}

\section{Histories of Polish Migrants in European Cinema}

Review of the book Polish Migrants in European Film 1918-2017 (2019) by Kris Van Heuckelom. The Belgian film scholar draws attention to fundamental problems regarding the theme of migration: the need to link local and global aspects in the study of the history of cinema, the possibility of situating film production in a transnational perspective, and the change of the image of Polish migrants over time. 
Kris Van Heuckelom tries to address the question how cinema supported common stereotypes and how it reflected a certain way of thinking that has placed the East in opposition to the West and tradition in opposition to modernity. The chronological arrangement of the book allows the author not only to capture the significant political and social changes taking place in Europe, but also to show their impact on the ways in which the migrants have been portrayed in films. One should emphasize particularly the valuable originality of the parts of the book in which Van Heuckelom presents his argument, referring to the films rarely mentioned by other authors, and draws attention to their uniqueness in comparison with the mainstream film production. 